\title{
A OPRESSÃO MATERNA EM SELO DAS DESPEDIDAS, DE HELONEIDA STUDART
}

\section{THE MATERNAL OPPRESSION IN SELO DAS DESPEDIDAS, OF HELONEIDA STUDART}

\author{
Enedir Silva SANTOS ${ }^{1}$ \\ Kelcilene Grácia RODRIGUES ${ }^{2}$
}

\begin{abstract}
Resumo: A figura materna resulta em um estereótipo moldado por sentimentos de zelo e abnegação. Este modelo é reforçado pelas mídias, pela religião e também pela literatura, principalmente a escrita por homens, que insistem em veicular a imagem de boa mãe, pois pela responsabilização - um dos pilares da sociedade - ocorre o incentivo à sedimentação de um dos lugares sociais ocupados pela mulher. Entretanto, a maternidade não é feita apenas de flores e do amor materno, como demonstra Badinter (1985); à literatura feita por mãos femininas, por meio da representação, como evidenciam Castello Branco e Brandão (1989), cumpre o dever de desconstruir essa ideia, revelando os lados positivos e negativos desse papel. Em Selo das despedidas, Heloneida Studart evidencia a opressão materna por meio da exposição da trajetória familiar das Nogueira de Alencar. Neste romance, evidenciamos as marcas da maternidade na criação das meninas-mulheres, pois se percebe que a opressão é repassada, sucessivamente, de mãe para filhas, o que incorre em transgressão e resistência uma vez que personagens distintas rompem a castração materna e social.
\end{abstract}

Palavras-chave: Narrativa. Autoria Feminina. Romance. Maternidade.

Abstract: The maternal figure results in a stereotype wrought by feelings of care and self-denial. This model is reinforced by the media, by religion and also by literature, especially written by men, who insist on conveying the image of a good mother, since the incentive to sedimentation of the social place occupied by her is one of the pillars of society. However, the maternity is not only made of flowers and maternal love, as demonstrated by Badinter (1985); to the literature made by feminine hands, through representation, as Castello Branco and Brandão (1989) show, fulfills the duty to deconstruct this idea, revealing the positive and negative sides of this role. In Selo das despedidas, Heloneida Studart evidences the maternal oppression through the exhibition of the family trajectory of the Nogueira de Alencar. In this novel, we evidence the marks of motherhood in the creation of girls-women, because it is perceived that oppression is passed on from mother to daughter successively, which leads to transgression and resistance once distinct characters sever maternal and social castration.

Keywords: Narrative. Female Authorship. Novel. Maternity.

\section{Considerações iniciais}

A literatura brasileira constitui-se como um cenário interessante no que se refere às abordagens sobre as questões de gênero: dicotômicas, brancas e patriarcais; ao mesmo tempo em que seu alcance, devido à hipervalorização do texto masculino em detrimento do texto de

\footnotetext{
${ }^{1}$ Doutora em Letras - Estudos Literários pela Universidade Federal de Mato Grosso do Sul. Diretora escolar da rede municipal de São José do Rio Preto, São Paulo. E-mail: <enedirss@ @otmail.com>.

${ }^{2}$ Doutora em Estudos Literários pela UNESP/Araraquara. Docente do Curso de Letras e do PPG-Letras da Universidade Federal de Mato Grosso do Sul. E-mail: <kelcilenegracia@gmail.com>.
} 
autoria feminina, forja e mantém enredadas por uma série de entraves a identidade da mulher, primeiro na ficção, posteriormente, reconhecendo o alcance representacional do texto literário, na realidade.

Caracterizamos a literatura brasileira como um "cenário interessante" por constatarmos, a partir de pesquisas como as desenvolvidas por Regina Dalcastagnè (2012), que o silenciamento impingido à mulher e a outros grupos, por fatores sociais, políticos, religiosos e comportamentais de fundo regulatório, serviu para que eles se pautassem sempre por uma ótica hegemonicamente masculina:

\footnotetext{
Nosso campo literário é um espaço excludente, constatação que não deve causar espanto, já que ele se insere num universo social que é também extremamente excludente. Falta ao romance brasileiro contemporâneo, como os números da pesquisa indicam de maneira eloquente, incorporar as vivências, os dramas, a opressões, mas também as fantasias, as esperanças e as utopias dos grupos sociais marginalizados, sejam eles definidos por classe, por sexo, por raça, por orientação sexual ou por qualquer outro critério.

O resultado é que, como conjunto, nossa literatura apresenta uma perspectiva social enviesada, tanto mais grave pelo fato de que os grupos que estão excluídos da voz literária são os mesmos que são silenciados nos outros espaços de produção do discurso - a política, a mídia, em alguma medida, também o mundo acadêmico (DALCASTANGÈ, 2012, p. 193).
}

Ocorre que o século XXI, diante das lutas pela representatividade e pelo exercício libertário de formação e exposição de identidades que se mantiveram enclausuradas nesses padrões, tem se constituído como um momento ímpar de transcendência dessa clausura; hoje, ainda não com a frequência desejada e nem no grande mercado literário, mas por pequenas editoras e em organizações como saraus urbanos e slams, eclode a voz dos silenciados: mulheres, negros, moradores das favelas, mulheres, homoafetivos, transexuais, entre outros.

Diante desse panorama de legitimação de outras vozes, ainda que tenhamos que atribuir à literatura o sobrenome composto "de autoria feminina" para diferenciá-la daquela que sempre foi assimilada como literatura legítima por ser escrita por homens, como constatou Regina Dalcastagnè, "Séculos de literatura em que as mulheres permaneciam nas margens, condicionaram-nos a pensar que a voz dos homens não tem gênero e, por isso, existiam duas categorias, a literatura, sem adjetivos, e a literatura feminina, presa a seu gueto" (DALCASTAGNÈ, 2012, p. 193). Foram consideráveis os avanços também no que diz respeito à literatura de autoria feminina.

Sabemos que a voz das mulheres vem ocupando maiores espaços na cena literária brasileira e no mercado editorial, por isso se fazendo ouvir e, consequentemente, estimulando representações outras. Esta luta pelo espaço e pela legitimidade remonta séculos atrás, em que 
escritoras como Maria Firmina dos Reis, Júlia Lopes de Almeida, Rachel de Queiroz, entre outras precursoras, encararam a árdua luta para fazer-se ouvir num contexto ainda mais excludente.

Lúcia Castello Branco e Ruth Silviano Brandão (1989, p. 16) abrem A mulher escrita com a seguinte manifestação: "Desejo de que haja um verbo feminino, gerador de novos espaços e inéditas veredas. Fim de um longo silêncio, tempo em que a palavra feminina é possível”. Na esteira dessa vontade, conjeturamos o caráter representacional que o texto, escrito pela perspectiva feminina, alcança no que se refere à desconstrução, à denúncia, à elucidação dos papeis desde sempre atribuídos às mulheres pela sociedade burguesa patriarcalista, pois como asseverou Simone de Beauvoir:

\begin{abstract}
Ninguém nasce mulher: torna-se mulher. Nenhum destino biológico, psíquico, econômico define a forma que a fêmea humana assume no seio da sociedade; é o conjunto da civilização que elabora esse produto intermediário entre o macho e o castrado, que qualificam de feminino. Somente a mediação de outrem pode constituir um indivíduo como um Outro (BEAUVOIR, 2016, p. 11).
\end{abstract}

Embasado pelas reflexões de Beauvoir, reverberamos que se antes do advento feminista bastava às mulheres adequar-se ao padrão, assimilando os modelos estereotipados pela perspectiva masculinista para não estar à margem; hoje, diante das ideias oriundas do empoderamento feminino, estar à margem ou na marginalidade, contribui para que se possam forjar novas identidades, ainda que em luta contínua diante do outro, sempre encarado como dominador.

Assumiremos, para este trabalho, a margem num contexto diferente do empregado por Regina Dalcastagnè (2012) na citação acima; o utilizaremos como um lugar de desvio, motivador para a transposição do enclausuramento, isto porque acreditamos que quanto mais textos de autoria feminina forem escritos e veiculados, maiores as chances da mulher se encontrar representada em suas questões - das mais ínfimas, às mais densas - a literatura como agente possibilitador de mudança ideológica e social necessária para alcançarmos valores como a sororidade e a igualdade.

Assimilada a literatura escrita por homens como voz sem gênero, a representação feminina sofre com a perspectiva que o masculino lança sobre ela, como nos mostram alguns dados da pesquisa de Dalcastagnè:

Há uma diferença significativa entre a produção das escritoras e dos escritores. Só como exemplo, em obras escritas por mulheres, $52 \%$ das personagens são do sexo feminino, bem como $64,1 \%$ dos protagonistas e $76,6 \%$ dos narradores. Para os autores 
homens, os números não passam de $32,1 \%$ de personagens femininas, com $13,8 \%$ dos protagonistas e $16 \%$ dos narradores. Fica claro que a menor presença das mulheres entre os produtores se reflete na menor visibilidade do sexo feminino nas obras produzidas (DALCASTAGNÈ, s/d, p. 2).

Postas tais informações, adentremos num dos sofrimentos que conta com a contribuição da voz sem gênero do texto masculino: a confirmação de estereótipos que atendem aos interesses da sociedade burguesa patriarcal, como o da moça que busca um casamento, da donade-casa, da boa filha, da boa mãe, da dissimulada espertalhona; enfim, de outras tantas imagens que, geralmente, se identificam com a mulher estabelecida pelos ditames sociais.

Este trabalho tem como objetivo pensar a relação da maternidade numa dupla perspectiva: como mãe que gera e cria; como filha gerada, criada e provavelmente genitora, no romance Selo das despedidas (2000), de Heloneida Studart.

Tendo como premissa a imagem da mãe forjada na cultura ocidental, procuramos refletir sobre a representação materna elaborada na escrita ficcional de Heloneida e em quais pontos esta representação revela características que salientam a desconstrução da imagem estabelecida, pois entendemos que diante da clausura social imposta ao ser feminino se estabelece um círculo vicioso dificílimo de romper: mulheres silenciadas e oprimidas geram e educam outras mulheres silenciadas e oprimidas; todas carregam um peso enorme por serem quem são e, ou lutam resistindo e transgredindo as imposições, ou buscam adequar-se a padrões violentos e excludentes para sentirem-se ou serem aceitas.

No texto de Heloneida, a maternidade é metáfora de um tipo de empoderamento bastante incômodo: a princípio é a mãe que assume uma postura machista e autoritária, instituindo uma família subserviente. Além disso, há a negação da maternidade, mulheres que não conseguem engravidar ou perdem seus filhos.

Encarando a ficção literária como um espaço de inúmeras significações, pretendemos evidenciar como o texto de Studart contribui para a reflexão sobre o papel da mãe e como a perspectiva feminina pode promover e representar o rompimento do ciclo de violências sofridas pelas mulheres e que é retratado pela e na vivência das personagens.

\section{Maternidade: apenas uma questão de amor?}

No Brasil, ainda hoje e diante das investidas do poder Judiciário com alguns facilitadores de reconhecimento de paternidade, temos uma imensidão de cidadãos que não têm o nome paterno nos documentos oficiais, todavia o da mãe está sempre lá. São ferozmente atacadas as 
mulheres que abortam ou optaram em não ter filhos; as que os abandonam ou destoam da idealizada boa mãe.

Bastam-nos olhares e ouvidos atentos para percebermos a conotação que a palavra mãe assumiu na contemporaneidade, aliás, seja disseminada pelo discurso econômico midiático, seja pelo religioso, político ou social, a figura da boa mãe é uma constante nos diálogos e mesmo nos textos literários, principalmente, nos de escrita masculina.

A esse respeito, a reverberação do papel de boa mãe que insistentemente percorre os discursos, engendra uma imagem idealizada que se consolida cotidianamente, ao mesmo tempo em que reforça um estereótipo que focaliza apenas um dos lados da maternidade: o embelezado pela cultura patriarcalista. Exemplos disso são as personagens D. Glória de Matacavalos, matriarca mantenedora e cristã; de Sinhá Vitória, sempre sonhando com um futuro melhor para os meninos maior e menor na cidade grande; da mãe anônima de Caderno de um ausente, sempre a ensinar e acolher a filha, dentre tantas outras.

A imagem materna social de hoje não foi uma unanimidade atemporal, essa imagem modificou-se através do tempo, como esclarece Elisabeth Badinter (1985), em $O$ amor conquistado: o mito do amor materno. A autora demonstra que, primariamente, houve um distanciamento do chamado instinto materno, cuja definição é um misto de proteção, acalento, carinho e cuidados que era despertado na mulher apenas por ela sê-lo e ter a capacidade de procriar.

Concomitantemente, aproximou-se do amor materno, que se referindo a um sentimento, resume as mesmas capacidades, humanizando-as; entretanto, o questionamento da autora é como pensar em amor como algo inerentemente despertado pela condição fisiológica da mulher, quando muitas crianças francesas eram entregues a suas amas desde o nascimento até os cinco anos de idade? Elisabeth Badinter revela que a imposição da maternidade e do amor materno como ideais de vida e de sentimentalidade são questões mais profundas que têm um fundo histórico e social a ser estudado em que devem ser consideradas a posição da mulher e as mudanças no papel e na imagem da mãe na sociedade burguesa patriarcal:

Mais precisamente, os defensores do amor materno "imutável quanto ao fundo" são evidentemente os que postulam a existência de uma natureza humana que só se modifica na "superfície". A cultura não passa de um epifenômeno. Aos seus olhos, a maternidade e o amor que a acompanha estariam inscritos desde toda a eternidade e natureza. Desse ponto de vista, uma mulher é feita para ser mãe, e mais, uma boa mãe. Toda exceção à norma será necessariamente analisada em termos de exceções patológicas. A mãe indiferente é um desafio lançado à natureza, a a-normal por excelência.

Em princípio, a lei natural não admite nenhuma exceção. Mesmo se substituímos o conceito de lei (universalidade) pelo de regra (geral), é necessário constatar que há 
demasiadas exceções à regra do amor materno para que não sejamos forçados a questionar a própria regra. O Amor, no reino humano, não é simplesmente uma norma. Nele intervém numerosos fatores que não a respeitam. Ao contrário do reino animal, imerso na natureza e submetido ao seu determinismo, o humano - no caso, a mulher - é um ser histórico, o único vivente dotado da faculdade de simbolizar, o que o põe acima da esfera propriamente animal. Esse ser de desejo é sempre particular e diferente de todos os outros. Que os biólogos me perdoem a audácia, mas sou dos que pensam que o inconsciente da mulher predomina amplamente sobre os seus processos hormonais. Aliás, sabemos que a amamentação no seio e os gritos do recém-nascido estão longe de provocar em todas as mães as mesmas atitudes (BADINTER, 1985, p. 14-15).

Em Badinter, e podemos refletir também a partir de Beauvoir (2016), com a maternidade, realiza-se o destino fisiológico da mulher, todavia, na sociedade, tudo o que envolve a maternidade, desde a gravidez, está envolto por uma visão bastante romantizada acerca desse papel desempenhado pela mulher. Em tempo, essa perspectiva também é relativa, parece-nos que algumas mulheres, principalmente as que possuem melhores condições econômicas, romantizam ainda mais o papel da mãe por meio de rituais que se estabelecem desde a escolha do momento ideal para a gravidez, passando pela escolha do enxoval, a preparação do quarto, os enjoos e um companheiro disposto a satisfazer suas vontades, o nascimento envolto pelo companheirismo e, depois disso, uma convivência entre mãe e filho que se efetiva no amor e nos cuidados, praticamente, devocionais.

Pouco ou nada se fala sobre as dores, impingidas à mulher no discurso religioso do Gênesis. Há uma gradativa diminuição da simbólica dor do parto, presente na sociedade brasileira pelo número altíssimo de cesarianas, além da hipervalorização de aspectos que, a princípio, parecem exaltar a identidade feminina como a lactação e a geração, mas que, na verdade, revelam certa manipulação do discurso patriarcalista, afinal, destinada ao amor materno, a mulher, obrigatoriamente deveria gerar, povoar a terra. $O$ que parece empoderamento advindo do caráter biológico, se mostra também como uma forma de oprimir a mulher, pois

A maternidade, tradicionalmente assumida como o alicerce da estrutura familiar, passou a ser controlada de várias formas, com uma surpreendente proliferação de discursos patriarcais que buscam entender e controlar o que se considera o 'imperativo da reprodução'. [...]

Ao longo de quatro anos de leituras sobre esta temática em obras teóricas e ficcionais, pude perceber uma mudança gradual da função maternal que se situa numa espécie de encruzilhada, já que a maternidade é ao mesmo tempo um dos pilares que sustentam o patriarcado mas também um elemento importante da identidade feminina: todos nós temos mães, mesmo as mulheres que hoje, felizmente, podem exercer sua sexualidade desvinculada da "inigualável missão que lhe distinguiu Jesus", como se pensava inquestionavelmente . A maternidade é um locus de poder e opressão, autorealização e sacrifício, reverência e desvalorização, aspectos complexos que precisam ser trabalhados a partir da ótica da mulher. (STEVENS, 2007, p. 2-3) 
A ótica das mulheres, aqui revelada pela ficção e pelos estudos críticos realizados por elas, revela-nos mães que destoam ou se afastam das figuras patriarcalmente idealizadas. Além de promover a desconstrução da figura da boa mãe, agregam outras perspectivas ao papel e a sua vivência, como a desromantização da relação entre mães e filhos, mais especificamente da relação com as filhas, em que raramente aparecem cumplicidade e entendimento, como se vê também em contos como "Uma branca sombra pálida", de Lygia Fagundes Telles (1998), e “Mãe, o cacete", de Ivana Arruda Leite (2004).

Na primeira narrativa, a voz mãe da mãe revela a culpa que sente pelo suicídio da filha. Essa culpa é o resultado da somatória de muitos preconceitos e de uma gama de sentimentos que mostram a frieza da genitora diante da provável homoafetividade de Gina. Sobre o conto, Dalcastagnè tece as seguintes considerações:

\begin{abstract}
O conto se amolda à ambiguidade dessa mãe, que, se por um lado não se conforma com a distância tomada pela filha (sempre trancada com a outra no quarto, ou em românticos debates sobre a essência da morte com o pai), por outro não deixa que ela a toque quando precisa de calor e afeto. Essa mãe, provavelmente frequentadora de divãs, sabe como lidar com o discurso da culpa, mas não com o objeto dela. Ao contrário de todas as outras, que são espaço de proteção, e muitas vezes de libertação, para seus filhos (e mesmo para si), a mãe de "Uma branca sombra pálida" aparece como uma figura cerceadora, desprovida de afetividade e cheia de conflitos interiores. Os perigos que a envolvem e à sua filha nessa relação marcada pela ausência de cumplicidade são quase inteiramente subjetivos (DALCASTAGNÈ, 1999, p. 153).
\end{abstract}

A narrativa de Ivana Arruda Leite é protagonizada por uma mãe e sua filha, entretanto é a voz da filha que narra a história e caracteriza a genitora como uma mulher preocupada consigo mesma, egoísta e agressiva.

A narração da filha evidencia que em sua criação sempre prevaleceu o egoísmo materno. O vínculo emocional-afetivo entre as duas era praticamente inexistente, pois a filha era encarada como um fardo, um peso que atrapalhava a vida da genitora. Dessa maneira, a figura da mãe representada afasta-se da imagem acalentadora e devocional, promovendo uma desconstrução do papel social conferido pela maternidade.

A vivência entre ambas marcou negativamente a filha que passa a abominar qualquer resquício da mãe em si. Embora ela tente excluir a mãe de sua vida, a presença dela é constante, assim como o repúdio pela figura materna. A culpa é invertida: se em Telles está na mãe por suas próprias reflexões, em Leite, é a filha que lhe impinge.

No conto "Mãe, o cacete", observa-se que ocorre a desvalorização do papel ligado à maternidade, criada pela ideologia patriarcal. A narradora/protagonista demonstra 
uma identidade fraturada, sua trajetória mostra que ela necessita resgatar-se e recompor-se. A narradora não quer parecer-se com sua mãe, rejeita veementemente este modelo, demonstra uma opção de vida ligada à anti-concepção, ao direito de poder escolher. $\mathrm{O}$ conto funciona como denúncia das dificuldades e frustrações herdadas pela filha de sua mãe (TEIXEIRA, 2010, p. 53).

Essa desconstrução do papel de boa mãe observado nas autoras elencadas também é encontrada nos romances de Heloneida Studart, com o diferencial de que em O pardal é um pássaro azul (1986), O estandarte da agonia (1981) e Selo das despedidas (2000) esta desconstrução é evidenciada através das gerações de famílias nordestinas, cuja matriarca assume, após a morte do marido ou mesmo anulando-o, seu lugar social. Dessa maneira, as tramas narrativas se estabelecem em cenários bastante determinados: casarões decadentes, mas ainda sustentados pelo orgulho e pelo sobrenome, por tabus quanto à sexualidade feminina, relações de poder político e religioso e matriarcas que assumem o caráter violento de chefes de família, fazendo valer, para manutenção de uma falsa moral, desde violências simbólicas, até castigos físicos, como se vê no trecho abaixo:

\begin{abstract}
Acho que mamãe, muito antes de mim, descobriu o quanto papai é débil. E é ele quem interpela Melba e lhe pergunta por que anda com esse ar enfeitiçado, um jeito de quem levita, apesar de sua robustez. Mamãe faz ameaças: "Debaixo desse teto honrado só ficam as donzelas exemplares e as esposas fiéis. Sempre foi assim na família Nogueira de Alencar e sempre será". (STUDART, 2000, p. 70, itálicos do original).
\end{abstract}

A postura das mães que povoam as obras de Heloneida representa várias nuances comportamentais da sociedade, desde a mãe que gera e cria mulheres oprimidas e que mais tarde se tornaram opressoras, até aquelas que transgridem a opressão ao se rebelarem contra a figura materna, seja pela negação da própria maternidade, seja desafiando as regras impostas.

\title{
Breve nota sobre Heloneida Studart
}

Uma rápida pesquisa pela internet pode nos apresentar a escritora, jornalista, deputada, feminista Heloneida Studart, mulher nordestina que transitou entre Fortaleza e Rio de Janeiro e marcou presença devido ao engajamento em questões sociais ligadas ao direito das mulheres e aos mais pobres.

Como autora literária, tem uma produção bastante ampla e consistente que se constitui de vários romances, alguns tratando diretamente sobre a temática da Ditadura militar brasileira, outros expondo e questionando a presença da mulher em nossa sociedade. 
Sua trajetória política e literária evidencia uma postura particular bastante engajada e que não deixa de ecoar em suas obras ficcionais, ilustrando as considerações de Sartre (2004) de que escrever não é um ato ilustrativo e que o leitor não é mera e puramente uma testemunha:

\footnotetext{
Falar é agir; uma coisa nomeada não é mais inteiramente a mesma, perdeu a sua inocência. Nomeando a conduta de um indivíduo, nós a revelamos a ele; ele se vê. E como ao mesmo tempo a nomeamos para todos os outros, no momento em que ele se $v \hat{e}$, sabe que está sendo visto; seu gesto furtivo, que dele passava despercebido, passa a existir enormemente, a existir para todos, integra-se no espírito objetivo, assume dimensões novas é recuperado. (SARTRE, 2004, p. 20).
}

Diante das considerações de Sartre, consideramos que a escrita de Heloneida é uma importante ferramenta no panorama literário brasileiro, porque o modo como a autora forja sua ficção revela às mulheres como a sociedade patriarcalista lhes domesticou, a ponto de que várias facetas da violência tenham sido assimiladas com naturalidade e agregadas ao cotidiano; aos homens, os textos de Heloneida revelam que as mulheres são fortes o bastante para transgredirem e que a voz da mulher se faz ouvir, mesmo pelas menores frestas. Afinal, como afirma Nelly Novaes Coelho:

O núcleo problemático de sua produção romanesca (toda ela centrada na situação da
mulher na sociedade de mentalidade patriarcal que é a nossa) gira em torno da
denúncia de que a opressão individual (sofrida pelas mulheres e pelos excluídos) é
fruto direto do sistema político-socioeconômico ainda vigente - de base patriarcal,
misógina e escravocrata. As situações dramáticas, que se enredam nas tramas
romanescas, giram em torno das várias formas de opressão exercidas sobre as
mulheres, principalmente as do interdito ou da exploração sexual. (COELHO, 2002,
p. 257).

Numa das situações dramáticas destacadas por Coelho, a figura da mãe como agente opressiva de outras mulheres evidencia que as bases dessa sociedade patriarcalista se fundamentam nos desvãos disseminados históricos e sociais, visando o controle do feminino e sua submissão diante do masculino. Dessa maneira, Selo das despedidas traz gerações de mulheres que estiveram sob o jugo familiar e que transgrediram rompendo o silêncio ou negando-se a participar do espetáculo de domesticação.

\section{Selo das despedidas: a desconstrução da boa mãe}

O romance Selo das despedidas (2000) é narrado por duas vozes: a primeira, um narrador onisciente que conta paralelamente a história da família Nogueira de Alencar em meados de 1940 e, no presente, das protagonistas Mariana, Leonor e Mimi - últimas mulheres da família. 
A segunda é a voz da tia Maria das Graças, cujos cadernos, espécie de diários, são enviados para a sobrinha Mariana após seu suicídio e relatam também a história da família, mas do ponto de vista da transgressora personagem.

No texto, o relato de Maria das Graças está disposto sempre em itálico, o que marca a presença gráfica e serve de ancoragem para a leitura, recuperando por meio da memória as bases educacionais familiares que influenciaram indiretamente os acontecimentos futuros de que participam Mariana, Leonor e Mimi.

A trama narrativa apresenta preponderantemente o papel das mulheres enquanto mães, filhas, irmãs e esposas e, nele, se entretecem denúncias de opressão, conforme atesta Coelho (2002), que têm sido omitidas na própria ação da mulher, uma vez que na atuação social, "como importante agente educador" acaba atuando como transmissoras e perpetuadoras dos valores patriarcais, de modos diversos vitimizando umas às outras.

De certa posição social no nordeste brasileiro, a família Nogueira de Alencar era enfática no intuito de defender o que considerava a moral e os bons costumes, para isso, doesse a quem doesse, as mulheres deveriam ser submissas aos homens e à família, aquelas que estavam predestinadas a não os terem, deveriam servir às mães. Neste panorama, a matriarca ergue-se como um totem que não pode ser profanado, ou seja, há um apagamento do homem enquanto companheiro, para que a mãe possa empunhar o símbolo fálico de poder. Este lugar e esta empunhadura lhe são assegurados pela observância das normativas sociais e pela maternidade.

Desse modo, a dor era destinada às mulheres que se contrapusessem à criação materna, pois não herdariam o totem, mas o aniquilamento advindo de suas transgressões. Nesse sentido, expondo tais paradigmas, a narrativa de Heloneida, a partir dos acontecimentos vivenciados pelas personagens, se constrói como um importante veículo de representação tanto da mulher enquanto educadora, quanto educada: promotora e sofredora das castrações.

A linhagem feminina da família é marcada por mulheres fortes, todavia adestradas para se sujeitarem aos ditames sociais impostos. Em primeiro plano, eram refreadas pela criação castradora das mulheres que por sua vez reproduziam os modelos perpassados; em segundo, pela comunidade com a qual conviviam que também não lhes admitia ascender. Dessa forma, o romance evidencia o mecanismo de dominação da mulher, assim como a desconstrução do amor materno que dá lugar a uma vazão de preconceitos e violências.

Em todo o romance é comum encontrarmos a punição das mulheres que manifestaram em seu comportamento o desacordo com os valores sociais vigentes: um misto de ditames religiosos, preconceitos de toda espécie, além de uma hegemonia masculina que se baseava no poder patriarcalista onipotente e indiscutível, muitas vezes também manifestado pelas próprias 
mulheres. Trata-se da exigência do silenciamento até o castigo físico, uma culpa que permeia as relações e pesa no pensamento e nas ações das personagens: “- Os culpados serão punidos murmurou Leonor, como se falasse sozinha. Mamãe sempre dizia isso quando éramos pequenas. Aliás, é uma experiência concreta das mulheres da nossa família” (STUDART, 2000, p. 21).

A primeira geração de mulheres da família Nogueira de Alencar era formada pela matriarca D. Pequenina, as filhas Maria das Graças, Mimi e Melba. Com uma postura similar a dos homens, a saber, não admitia questionamentos ou opiniões contrárias, a matrona governava a família com mãos de ferro, consequentemente, oprimia as filhas lhes infligindo os destinos que melhor aprouvessem aos próprios interesses, principalmente no intuito de manter os chamados bons costumes e as tradições familiares: "Mamãe servia, com parcimônia, a sobremesa. Desprezava os comentários de papai. Desprezava-lhe as cóleras. Ela é que era o chefe daquela casa, apesar de ser muda e frágil e se chamar Pequenina". (STUDART, 2000, p. 110, itálicos no original).

Aliás, antes de continuarmos, é preciso esclarecer que o poderio da família, advindo de relações comerciais e políticas passadas, encontrava-se em decadência já nos anos da primeira geração, como sabemos pelos escritos de Maria das Graças.

As mulheres da minha família não trabalham, mas mamãe finge não ver as apostilas
que acumulo para me habilitar a um concurso público. O dinheiro diminui, jarros de
terracota e opalina que foram do avô Isaías desaparecem dos seus lugares. Vez em
quando, encontro na sala de visitas, sentada no sofá de palhinha, uma parenta
chamada Carolina, que usa um camafeu no peito e é agiota. Mamãe fala vagamente
em fazer chapéus de senhoras para vender. É uma veleidade e uma ameaça a papai,
que se exalta, dobra o guardanapo e se retira da mesa. (STUDART, 2000, p. 61,
itálicos no original).

Nesse contexto social, encontramos Mimi, Melba e Maria das Graças, três irmãs encurraladas por uma mãe que a qualquer custo procura manter a honra da família, insistindo em fixá-la numa esfera econômica e social que não lhe era possível. Todavia, sair deste contexto significa colocar-se no mesmo patamar que o povo, desconstruindo todo o aparato de falsa moral que lhes envolvia as relações, pois embora vivessem em contextos próximos, o povo já dissolvera muitas das amarras que aprisionavam as mulheres Nogueira de Alencar.

Cada uma das filhas percebeu/sofreu a opressão materna de um modo distinto. A filha mais velha, Mimi, alia-se a mãe e apreende dela muitas características: é venenosa no trato com as irmãs, alcoviteira e dissimulada: "Mimi é sonsa, tem inveja da beleza de Melba e bisbilhota todas as histórias da cidade e da vizinhança”. (STUDART, 2000, p. 68, itálicos no original); 
"Calei-me. Mimi tinha falado. Os mecanismos do medo, da repressão e castigo estavam desencadeados. Era inútil argumentar contra sentimentos tão poderosos" (STUDART, 2000, p. 113, itálicos no original).

A opressão sobre Melba incidiu sobre a vivência de sua sexualidade. Tratada como uma pecadora ou como uma criminosa, as duas figuras poderiam ilustrar seu destino, foi encarcerada no Asilo Bom Pastor, lugar onde as mulheres desonradas eram presas para que não mais envergonhassem suas famílias.

1944. Estamos em 1944, mas é como se fosse a Idade Média. A justiça, para as
mulheres, é a da família. A família prende, julga e dá sentença. No caso de Melba, a
sentença é o internamento no Asilo Bom Pastor. Papai, o padre Peixoto, mamãe e o
tio Abílio chegaram a essa decisão. [... Foi isso que minha irmã alegre e formosa se
tornou: uma penitente. Papai foi agitar diante de Melba um velho manguá, retirado
de seus guardados. Sacudiu a tira trançada de couro diante de Melba.
- Se chegar perto da porta da rua, apanha até sangrar. (STUDART, 2000, p. 138,
itálicos no original).

O destino da personagem é a súmula de muitos preconceitos e violências cometidas contra as mulheres que não submetiam sua sexualidade aos ditames sociais. Há no romance outras passagens que evocam que o domínio da sexualidade feminina era atribuído ao masculino, primeiro aos pais e irmãos, depois ao marido. As mulheres não passavam de objetos de casa, por isso, o desejo lhes era negado, afinal, poderia ser porta de entrada para outras transgressões e descobertas.

[...] Melba queria me jurar que tínhamos sido educadas na mentira. $O$ amor físico não era sujo nem penoso, não era apenas um dever humilhante a ser cumprido pelas donas casadas, um sacrifício oferecido no altar do matrimônio. O amor físico era um esplendor da natureza, uma alegria tão grande que era preciso gritar para proclamálo. E ao me afirmar isso, Melba soltou um grito e tive e fechar-lhe a boca com a palma da mão, para que não a ouvissem. (STUDART, 2000, p. 73, itálicos no original).

O discurso de Melba ecoado pela voz de Maria das Graças ilumina a escuridão propositalmente disseminada sobre a vivência da sexualidade feminina. Mais do que isso, derruba uma das castrações sobre as quais se embasaram pilares de silenciamento, violência e submissão durante séculos em nossa sociedade.

Sobre Melba, a repressão materna foi endossada pela religião, pois o padre, guia espiritual da família, orientou as providências a serem tomadas, que a moça fosse confinada no asilo, de onde só saiu porque contraiu tuberculose, ou seja, como o discurso de Mimi anunciou acima, os culpados merecem suas punições. 
- Mamãe, impeça essa vergonha. É sua filha!

Respondeu, surdamente, que Melba já não era sua filha. Suas filhas éramos nós, Mimi e eu, virgens, que precisávamos ser defendidas da presença da perdida. Sem dar palavra, Melba foi se deitar para entregar-se ao exame ginecológico. Estava muito pálida. Teria descoberto que ser mulher é isso, é não ter direito nem mesmo à trincheira do próprio corpo? (STUDART, 2000, p. 117, itálicos no original).

A personagem Maria das Graças, voz da transgressão inserida na primeira geração dos Nogueira de Alencar, também sofreu as castrações maternas desde a infância. D. Pequenina exige que a filha cumpra a tradição familiar: que ela abdique do casamento e da vaidade e destine-se aos cuidados da mãe idosa, "Mas é apenas uma astúcia de mamãe. Ela sabe que a escolhida para ser uma velha donzela a seu serviço sou eu mesma". (STUDART, 2000, p. 68, itálicos no original). Mais do que isso, Maria das Graças, ironicamente, continuava a linhagem de mulheres pensantes da família, por isso, caiu em desgraça também: perante os olhos da mãe, deveria apenas aceitar seu destino de servilidade filial, pois escrever, pensar e argumentar era maldição na boca de quem somente deveria calar-se, afinal, essas ações fomentariam resistência.

Entretanto, a personagem transgride as normas familiares e as imposições maternas com ações que vão do questionamento, até a ousadia de escrever textos e ter uma vida econômica, o que era negado às mulheres da família. Sente as marcas da castração, mas não se dobra a elas, evidência disto é que sua voz nos faz conhecer os absurdos cometidos em nome dos valores contra as mulheres, "Sei que a ansiedade me tira o sono e não posso parar de pensar na sorte sinistra das mulheres do meu sangue, as que se rebelaram" (STUDART, 2000, p. 165-166, itálicos no original).

Maria das Graças, ao contrário de Mimi, sensibiliza-se com o destino imposto a Melba, todavia, não apenas pelo laço fraterno, na verdade, ela é a única que parece entender que embora a aparente naturalidade permeie as relações familiares e sociais, as violências cometidas por todos os lados vitimizam, martirizam a existência das mulheres.

E era inútil tentar lançar a sociedade contra a costureira, porque ninguém condena um homem que se aproveita de uma moça desfrutável.

- Mamãe, você não ama sua filha - disse eu, na sombra da alcova. - Você não ama nenhuma de nós, visto que estamos expostas a um futuro assim medonho.

- Fui vítima da má-sorte - gemeu ela. - Por tudo isso, sempre quis ter um filho homem. Por que Deus não ouviu minhas preces e não me deu um meninozinho, que mijasse em pé e me adorasse? (STUDART, 2000, p. 141, itálicos no original).

O martírio de ser mulher nesta sociedade é reafirmado pelas palavras da mãe que não acolhe as filhas, as condena. Contaminada pelos julgamentos patriarcalista, D. Pequenina aparece como boa mãe perante a sociedade, uma vez que pune os erros e exige um 
comportamento exemplar, mas uma algoz, reprodutora dos valores patriarcais que mutilam mulheres desde sempre. Este jogo de aparências entre a figura social da boa mãe e a face castradora que a mulher assume perante seus filhos confirma as palavras de Elisabeth Badinter (1985, p. 17) de que o amor materno existe, mas não para todas as mulheres, "não é só o amor que leva a mulher a cumprir seus "deveres maternais". A moral, os valores sociais, ou religiosos, podem ser incitadores tão poderosos quanto o desejo da mãe".

A moral, os valores sociais e religiosos, todos eles influenciados por uma ótica patriarcalista, norteavam os passos e as atitudes tanto de D. Pequenina, quanto de D. Mimi, por isso geraram: para não se sentirem menorizadas perante outras mulheres, mas os sentimentos que a maternidade lhes despertou as afastam da figura idealizada, como denuncia a narrativa de Heloneida, aproximando-as de uma realidade mais comum do que se imagina, como se percebe nas palavras da personagem Leonor:

\footnotetext{
- Tem de me ouvir - disse Leonor. - Por que cortou minhas asas? Por que me criou como uma bonequinha de luxo? Você queria que eu me casasse com um homem rico, não queria? E aí eu cheguei aos 24 anos e você queria que eu casasse com qualquer um.

De repente, interrompeu suas acusações e começou a soluçar. Era a primeira vez que chorava depois do crime.

- Não me conformo dela não ter nos amado - gemia. - Ai, Mariana, fique certa disso: ela nunca nos amou. (STUDART, 2000, p. 240).
}

A mutilação a que nos referimos é, primordialmente, a psicológica de que a segunda geração das mulheres Nogueira de Alencar é também vítima. Esta geração tem origem na maternidade de Mimi, a única que constituiu família e seguiu reproduzindo muitos dos passos de sua mãe: casou-se com um homem pobre e anulado em todo o relacionamento, encerra-se numa vida de aparências que contempla desde a situação financeira, até as sentimentalidades demonstradas para os outros.

A personagem teve duas filhas, desprezando uma delas, Mariana, relegando-a ao posto de velha donzela e apostando em Leonor, a quem a mãe preparou para um casamento magnífico e uma vida de conforto. Na segunda geração, também cada filha é afetada pela opressão materna, seja pelo desprezo, seja pelas manipulações que naturalizam as violências cotidianas.

Nessa idade já acabara para Mariana a esperança de ser aceita e amada por sua mãe. Os anos de obediência e silêncio da primeira infância, o medo estoicamente suportado, os bons modos à mesa as notas mais altas da escola, tudo isso estava terminado, esvaído. Todo aquele comportamento de menina aplicada só tinha uma finalidade: atrair a atenção da mãe, merecer sua aprovação, seu carinho. Tempo perdido. Dona Mimi só tinha olhos para a filha mais nova, a quem permitia tudo: brincadeiras com seus sapatos de salto alto, pantomimas em que compareciam as camisolas bordadas, 
os vestidos de gala e até os colares de pérolas de várias voltas. Leonor se parecia com ela: "É a minha cara: loura e cacheada. Quando a parteira, dona Mocinha, me mostrou minha caçulinha. fiquei consolada da decepção que tive ao ver o rosto de índia de Mariana. Mariana, coitada, se parecia com sua tia Maria das Graças, que ficou no caritó". (STUDART, 2000, p. 11).

Não foi apenas na aparência que Mariana saiu à tia, foi também no caráter pensante e transgressor: advogada, luta por causas ligadas à ditadura, apoia a irmã, casou-se e com tudo isso, frustrou as perspectivas de sua mãe que também queria castrá-la destinando-a à servilidade materna.

Não que Mariana tenha conseguido escapar ilesa, aliás, nenhuma das filhas escapou. Pelo contrário, como vimos na citação logo acima, o desejo de ser amada e aceita pela mãe influenciou várias atitudes da garota que acabou se desiludindo com a frieza, o egoísmo e a futilidade da mãe, que na narrativa presentificada continua sendo a sonsa alcoviteira descrita por Maria das Graças, "Quando estava com sua mãe, o tempo era igual ao dos pesadelos: não passava” (STUDART, 2000, p. 32).

Denunciada pelo narrador, percebemos em Mimi as características herdadas da mãe: com Mariana a arma utilizada foi o desprezo, com Leonor, foi o excesso de investimentos que incidiram em fracasso e, consequentemente, também em desprezo. Leonor, criada com tantos mimos, não escapou da maléfica influência materna: casou-se com um homem pobre, religioso fanático pela moral e tão castrador quanto a mãe. Aliás, no trecho a seguir, num diálogo entre elas sobre o casamento fica evidente que a mãe oprimida, gera e mantém a filha na mesma redoma opressiva:

[...] As mulheres da minha geração não se entregaram, elas foram estupradas. Todas, ou quase todas. [...] Ele me agarrou, bufando, me chamou de estúpida, perguntou se eu pensava que casamento era brincadeirinha de criança. Eu gemia e soluçava, mas assim mesmo ele me atirou na cama e me rasgou inteira. Estupro, minha filha. A camisola do dia virou um farrapo sanguinolento. [...] Você, Leonor, não me atormente mais. Se eu fiquei casada, você também pode ficar. É da nossa sina. (STUDART, 2000, p. 97-98).

A personagem Mimi não consegue sustentar o totem que herdou de sua mãe devido a sua própria personalidade, mimada e egocêntrica, não se importa com as filhas, apenas com o que elas podem lhe proporcionar. A derrocada da mãe como castradora se deslinda pelo enredo em pequenas subjetividades: obrigada pelo marido a vir para o Rio de Janeiro, perde a base da sociedade que lhe blindava enquanto matriarca; tem que se adaptar a uma vida sem os pequenos luxos a que estava acostumada, inclusive passa a viver sozinha em um apartamento, ou seja, ao 
contrário de Maria das Graças que permaneceu no casarão, Mariana deixou a mãe e só a visita por obrigação.

Durante todo o percurso da narrativa, ela é um peso difícil de ser carregado e só é minimizado quando as filhas rompem com algumas das amarras infligidas pela mãe: Mariana aceita seu destino de esposa e mergulha em sua tristeza pela vida que não teve - "Mariana sacudiu outra vez os ombros e estendeu a mão ao desconhecido com quem - agora estava decidido - viveria até o fim dos seus dias" (STUDART, 2000, p. 256). Leonor liberta-se da prisão do casamento com o assassinato do marido: “- Leonor não permitirá. Ela não vai deixar

que ninguém lhe tire a glória do crime. Tem isso como um galardão. Compreenda. É o único feito de sua vida medíocre e anônima" (STUDART, 2000, p. 223).

As filhas conhecem a mãe que tem e cadeia repressiva em que ela tenta prendê-las, por isso, durante todo o enredo vemos desconstruir-se a figura da boa mãe e ao final das duas narrativas, é a transgressão quem tonifica essas relações: Maria das Graças se suicida no velho casarão hipotecado da família; Mariana segue a vida, lutando pelas causas que acredita e Leonor vinga-se do marido assassinando-o e expondo-se, regozijada. Desatando as amarras, as mulheres Nogueira de Alencar resistem à opressão materna.

\section{Considerações finais}

A desconstrução da imagem da boa mãe permeia toda a narrativa de Selo das despedidas (2000). O enredo demonstra que na questão da maternidade e no desempenho desse papel há muito mais que amor, como apontou Badinter (1985), há fatores externos que influenciam diretamente escolhas e comportamentos, muitos deles fundamentados em práticas embasadas por uma orientação patriarcalista que objetivando manter o controle, submetem as mulheres a vivências castradoras e subalternizantes.

O modo como a narrativa de Heloneida Studart expõe a vivência da maternidade e sua repercussão na vida das filhas, contribui para a desconstrução desse papel, ao mesmo tempo em que se configura como uma vitrine dos malefícios ocasionados pela orientação patriarcalista na educação e na criação das mulheres e que é recorrente nos discursos sociais.

Expostas em D. Pequenina e D. Mimi estão as características que impulsionam a maternidade atrelada a certo status social, uma vez que não ter filhos também é algo marginalizado em nossa sociedade.

O fato é que encontramos vários tipos de mulheres descritas na narrativa de Heloneida, assim como encontramos várias formas de silenciamento e opressão; todavia, o que talvez haja 
de mais importante em todo o corpo narrativo, são os ecos de resistência que se erguem também a qualquer custo. Estes ecos partem das vozes femininas que transgridem as normas comportamentais, sexuais e sociais para representar uma gama cada vez maior de mulheres que não se contentam com o lugar ocupado ou com os papeis destinados.

No texto, a transgressão final fecha também todas as possibilidades de recondução do papel da mãe como algoz de outras mulheres: Maria das Graças, suicidou-se, Mariana não teve filhos; Leonor, presa, também não gerou. Findaram-se as Nogueira de Alencar e com elas a probabilidade de levar adiante a maternidade como um peso e a postura materna como uma forma de opressão de outras mulheres.

\section{Referências}

BADINTER, Elisabeth. $O$ amor conquistado: o mito do amor materno. Trad. de Waltensir Dutra. Rio de Janeiro: Nova Fronteira, 1985.

BEAUVOIR, Simone de. O segundo sexo: a experiência vivida, vol. 2. Trad. de Sérgio Milliet. 3. ed. Rio de Janeiro: Nova Fronteira, 2016.

BRANCO, Lúcia C.; BRANDÃO, Ruth S. A mulher escrita. Rio de Janeiro: Casa Maria Editorial: LTC, 1989.

COELHO, Nelly N. Dicionário crítico de escritoras brasileiras: 1711-2001. São Paulo: Escrituras Editora, 2002.

DALCASTAGNÈ, Regina. Literatura brasileira contemporânea: um território contestado. Vinhedo: Horizonte, 2012.

DALCASTAGNÈ, Regina. A construção do feminino no romance brasileiro contemporâneo. s/d. Disponível em: http://www.crimic.paris-sorbonne.fr/IMG/pdf/dalcastagne.pdf Acesso em: 10 ago. 2018.

DALCASTAGNÈ, Regina. Espaço de cumplicidade: a representação da figura materna na literatura brasileira contemporânea. 1999. Disponível em: http://periodicos.unb.br/index.php/cerrados/article/download/13319/pdf_292 Acesso em: 13 ago. 2018.

LEITE, Ivana A. Mãe, o cacete. In: RUFFATO, Luiz (org.). 25 mulheres que estão fazendo a nova literatura brasileira. Rio de Janeiro: Record, 2004. p. 213-216

SARTRE, Jean-Paul. Que é a literatura? Trad. de Carlos F. Moisés. 3. ed. São Paulo: Ática, 2004.

STEVENS, Cristina Maria Teixeira. O corpo da mãe na literatura: uma ausência presente. 2007. Disponível em: 
http://www.repositorio.unb.br/bitstream/10482/3785/1/CAPITULO_CorpoM\%C3\%A3eLiter atura.pdf Acesso em: 10 ago. 2018.

STUDART, Heloneida. Selo das despedidas. Rio de Janeiro: Ao livro técnico, 2000.

TEIXEIRA, Níncia Cecília R. Borges. Mãe e monstro: A desconstrução da figura materna na escrita de autoria feminina. Revista Terra roxa e outras terras: Revista de Estudos literários. Londrina, v. 20, p. 46-55, 2010. Disponível em:

http://www.uel.br/pos/letras/terraroxa/g_pdf/vol20/TRvol20e.pdf Acesso em: 10 ago. 2018.

TELLES, Lygia F. Uma branca sombra pálida. In: . A noite escura mais eu. 4 ed. Rio

de Janeiro: Rocco, 1998. p. 127-142.

Recebido em 28/08/2018

Aceito para publicação em 10/12/2018 